\title{
Establishing Two-Oriented Society and Environmental Accounting
}

\author{
Xiao-Hua LIN ${ }^{1, a,{ }^{*}}$
}

${ }^{1}$ Business School, Wuhan Yangtze Business University, Wuhan, Hubei 430065, China

a2442813799@qq.com

${ }^{*}$ Corresponding author

\section{KeyWords: Sustainable Development; Two-oriented society; Environmental Accounting}

\begin{abstract}
Sustainable development not only meets contemporary people' needs, but also the offspring's needs. This paper described Two-oriented society construction which is the requirements of sustainable development from the perspective of sustainable development,And environmental accounting promotes the construction of Two-oriented society means, enabling enterprises to disclose information in the environmental institutional framework, and true disclosure of environmental information is implementation of environmental resources reasonable arrangements, Which meets the socio-economic sustainable development.
\end{abstract}

\section{Introduction}

In 2005, "the national economy and social development in the 11th Five-year plan" was endorsed in the fifth plenary session of the sixteenth central committee. The ideal of building the resources conserving and environment friendly society was first proposed, and the thought of economizing resources and protecting environment was regarded as basic national policy. The construction of the resources conserving and environment friendly society must be given priority in preindustrial and modern development strategy." it was clearly emphasized in the report of seventeenth national congress of the communist party of China. The construction of two-oriented society is the abbreviation of the resources conserving and environment friendly society.

Firstly, the key to the transform and creation of the construction of two-oriented society is to improve the method of leadership. From the general situation, we should transform government functions positively and jump out from the thinking model of partial interest. To unify ideas into the strategic decision of two-oriented society and the overall deployment. To raise awareness and carry out the energy-conserving and environment-protection task well. Related industries and enterprises, especially the leader of high energy consuming and heavy-duty corporations, need to widen their vision further and transform their management concepts, relating its development to the nation's overall economic construction, try to move forword the economic and environmental friendly development path, avoid sinking into vicious circle of contesting resources and damaging environment.

Secondly, the key to the advance rate and quality is to constantly transform the development patters. It is in the high speed of growth stage, quantity expansion is needed to be fully released. But the way of economic development must be transformed. We should go a better and faster development path.

Thirdly, the key to impel the passion and power of social construction is to constantly enhance the aim of benefiting the people. Energy and environment are two basic points for the development of economic society, but everything lies in the harmony and happy life of people. To exchange large consumption of the limited resources and the damage of natural environment for the development of economy is unworthy. The construction of two-oriented society should be combined with the current demands of the people to form a harmonious society and realize the harmony between human and nature.

Humans should economize resources, reduce pollution, protect the environment and keep well with nature. Only in this way, can humans build a two-oriented society. Environmental accounting 
recorded in the way of environmental pollution cost can promote the construction of two-oriented society.

\section{Chinese environment and environment accounting}

\section{A. China's Environment Conditions}

There are around 200 million tons of pollutants poured into the rivers and lakes every year,200 million tons of lead,8 million tons of arsenic, More than 10,000 tons of mercury, 5500 tons of cadmium injected into the air, 3.7 million tons of greenhouse gas emissions into the atmosphere, 30,000 tons of waste were produced out of the factory. China environmental situation was serious, and the information released by the former State Environmental Protection Administration. There were wastewater 36.5 billion tons and industrial solid waste production of 600 million tons in China. By2007,Ministry of Environmental Protection of the People's Republic of China pointed out that water pollution situation was still grim, and seven major rivers were so pollution . 407 sections of 197 rivers,Cross-section ratio of grade I III,grade IV V, worse than grade V is $49.9 \%, 26.5 \%$ and 23.6\%.Among this, Pearl River and Yangtze overall is of good water quality, Songhua River is of light pollution, Yellow and Huaihe river are of moderate pollution, Liaohe River, Haihe River are under heavy pollution. Industrial solid waste productions are 175-767 tons, 13.818 million tons of chemical oxygen demand emissions, 24.681 million tons of sulfur dioxide emissions.

\section{B. Environmental Accounting}

With economic development, environmental issues have become increasingly prominent, governments are increasingly committed to environmental issues, A series of environmental regulations, and information disclosure requirements were introduced. Meanwhile, with the democratization of society and the development of ecological civilization, Environmental information disclosure has become a new trend in sustainable development of the country's development.

On September 25, 2006,the Shenzhen Stock Exchange Promulgated Shenzhen Stock Exchange Listed Companies Social Responsibility Guidelines, at the first time promote listed companies actively committed to social responsibility to encourage voluntary disclosure of information on environmental pollution. So far, in most countries of the world social and environmental information disclosure is voluntary. By 2006 China emissions of major pollutants don't drop but increase, every two days to occur with sudden environmental accidents on average, Public environmental complaints increased by $30 \%$, The instructions of the central leadership on environmental issues than in 2005 increased by $52 \%$. To this end, China annual energy savings of $4 \%, 2 \%$ emission reduction requirements in the Eleventh Five-Year Plan, Requiring companies to disclose environmental information, to fulfill their social responsibilities.

Environmental accounting is a branch of accounting, environmental protection, environmental assets , environmental liabilities, environmental costs, environmental benefits for the accounting of the content , in money as the main form a variety of measurement instruments, the relevant environmental legislation and regulations based on measurement, recording and reporting on environmental issues involved in the production and operation activities and their results . External environmental accounting, the main goal is to provide useful environmental accounting information, and information disclosure is an important program of environmental accounting information system , enterprise only through the disclosure of environmental accounting information is passed to the information users .

Chinese economic growth of GDP, at least 18 percent rely on the resources and ecological environment overdraft obtained. The deterioration of resources and ecological environment affect the accumulation of wealth and quality of Chinese nationals. As environmental issues become more prominent, environmental accounting for the relations between environment and economic becomes more and more important. Environmental issues are both macro and micro issues. 


\section{Suggestions for the construction of environmental Accounting of China}

\section{A. Government promotes the development of environmental accounting.}

Researches both domestic and aboard indicate that government is the most powerful binding force in promoting society, enterprises and organizations to strengthen environmental management and promote environmental accounting practices. Our government attaches great importance to environmental issues, but environmental policy practical measures need multi-party co-operation and long-term efforts.

Improve the environmental regulations. Improve the environmental regulations and strengthen law enforcement, the legislation should reflect the principle of "prevention first" and avoid regulating and punishing after have serious consequences. The environmental laws need to be improved and perfected ulteriorly in many aspects such as system, coverage, rules for the implementations and operability, etc.

Draft environmental management standards and environmental audit guidelines. To draw lessons from international standards, and draft the uniform environmental management standards and environmental audit guidelines of China and encourage business organizations to make strategic plans and objectives considering the environmental impact, guiding the enterprises to carry out effective environmental management so as to better participate in international competition.

Use economic lever. Take full advantage of economic lever to protect and govern environment. From the long run, environmental protection and economic development are mutual reinforcing with sustainable development. Therefore, on the one hand, the tax authorities should study and make corresponding operational rules, and to make environmental management have a more consistent evaluation criteria, so that the environmental costs related to the processing will have rules to follow. On the other hand, the Government amends the tax bill, and to actively guide companies to protect and govern environment and give favorable tax revenue and make use of "green tax" to encourage and support enterprises that do better in the environment.

Establish and improve laws and regulations related to environmental accounting. Establish and improve laws and legal system related to corporate environmental accounting, to lay out the legal foundation. Learn from the Japanese government first through the development of laws and regulations. Continue to establish and improve environment-related laws and regulations system, and to lay the sound legal foundation for the implementation of corporate environmental accounting.

Make guidelines that related to corporate environmental accounting. Learn from the Japanese government to implement of measures for the implementation of corporate environmental accounting, the government is the leading authority to make standards, guidelines of corporate environmental accounting and enable enterprises to carry out environmental accounting practical work according to rules while strengthening supervision and guidance.

\section{B. Social development promotes development of environmental accounting.}

In the days that the loss of forests, soil erosion, desertification of grassland, serious water pollution, ground subsidence and other environmental problems increasingly serious, people should be aware of the human environmental resources should be used appropriate and for compensation to maintain sustained economic development, so that not only meet the social and economic development objective and ensure steady economic growth, but also to ensure social and ecological environmental objectives and ensure that human and nature harmonious development.

China continued to introduce environmental management system and environmental fee system from Europe, the United States, Japan and South Korea, to form good social foundation for the advancement of environmental accounting. Accounting associations, academia and the corporate division of assist promote and reward, strengthen academic research and international exchanges, which have greatly facilitate the public participation of environmental management and enhance public awareness of the environment, promoted the implementation and promotion of 
environmental accounting to make enterprise environmental information to be able to give full play to role.

To take full advantage of the role of mass media and widely publicized environmental protection laws and regulations to strengthen environmental protection basic knowledge and education of environmental awareness, to use of the public growing concern on environmental issues and form public pressure to promote the enterprise's economic development and environmental protection as a precondition and full disclosure the impact of enterprises on the natural environment. Meanwhile, adhering to the principle of rewards and punishments both to increase the environmental protection law enforcement and carry out the environmental accounting rewards and penalties system, penalties and rewards, to encourage enterprises fully aware of the responsibilities of various stakeholders in business activities, while maximizing their own interests so as to maximize the benefits of the enterprise and the whole society, to strengthen the training of environmental accounting job accounting personnel, to organize environmental accounting journals as soon as possible so that to increase the implementation of the propaganda of the environmental accounting.

\section{Strengthen the supervision and guidance of government departments and intermediaries}

In September 2003, Environmental Protection Administration of China issued a bulletin on corporate environmental information disclosure, which provides the content and methods of the enterprise "must" and "voluntary" public information, but the provisions are too simple and specific implementation is almost a dead letter. Compared with advanced countries in the world, China's State Environmental Protection Administration has not yet relevant criteria such as environmental accounting, guide the formulation included in the scope of work.

To achieve pollution reduction task is not only the main task of levels of government and the environmental protection department, but also the main task of each enterprise. Moral values of the environmental responsibility of many corporations are not strong. Behavior of non-sustainable development such as the thought of "value economy and slight environment" and "pollution first, treatment later" is much more common. Enterprise shortsighted economic interests and weak awareness of environmental protection and attach little importance to environmental accounting. State environmental protection departments should deal with polluting enterprises with strict administrative penalties, to strengthen the environmental awareness of social responsibility from the regulation, and to create a good objective and subjective environment for enterprise to carry out environmental accounting.

State Environmental Protection Administration in conjunction with other government departments, to study the theory of environmental accounting and break through the barriers to the practical operation, and to study and formulate environmental accounting standards and guidelines that are suitable for China's national conditions and enterprises of different sizes, and to regulate the object of environment accounting, and to determine specific projects and guidelines that must be recorded by economic sectors and strengthen the supervision and guidance of implementation of environmental accounting work, and to encourage enterprises to gradually improve the disclosure of environmental information further the corporate environmental accounting system.

\section{Improve environmental theory system of China}

Sustainable development of enterprises is the basis and prerequisite for the establishment and development of environmental accounting while the existence of environmental accounting is the objective requirements of the corporate strategy of sustainable development. China's Environmental Accounting Theory system are the goal of environmental accounting, environmental accounting assumption, the object of environmental accounting and recognition, measurement and accounting reports of elements of environmental accounting.

As an important branch of modern accounting, environmental accounting is a newly developing interdisciplinary subject of great practicality and applicability. On a worldwide scale, its content and methodology has not yet been finalized. Chinese environmental accounting, whether for theory or practice, started even later. The research of theory of environmental accounting is not only the 
needs of the development of environmental accounting discipline itself, but also an urgent need for the guidance of environmental accounting practices of China. There is no substantive breakthrough in environmental accounting in the measurement of link and there is no theoretical guidance in environmental accounting practices, which form the difficulties of environmental accounting practices. Therefore, we need to strengthen the research of theory of environmental accounting and establish environmental accounting theoretical system suited to China's national conditions.

\section{E. Focus on research of cross-disciplinary use}

Environmental accounting is a new interdisciplinary and boundary principle established to solve interdisciplinary problems of environmental management under the new conditions, it is another innovation and development of accounting. The knowledge structure of the environmental accounting including accounting, environmental studies, environmental economics, ecological economics, sustainable development, and industrial ecology knowledge and so on, in which accounting is basic theory,and this is the basic reason that the environmental accounting is concluded in the accounting scope, namely basic theory of accounting, basic program of accounting and basic methods of accounting. To research accounting of the environment can not only standing on the accounting perspective, but also should focus on interdisciplinary and cross-use study, and to combine accounting with many other disciplines such as environmental studies and other related principles so as to solve problems in environmental accounting and report and promote environmental accounting and reporting of research methods more scientific and reasonable, making the system of environmental accounting theory more comprehensive.

\section{F. Promote the international exchange of environmental accounting}

The West had more mature results and practices both in the theoretical study and practical operation of the environmental accounting. We can make full use of Backward Advantage, to continue to strengthen the international exchange of the environment, to absorb and learn advanced Western theories and methods. Meanwhile, publish the theoretical and practical experience of environmental accounting of China to promote the worldwide development of environmental accounting. Absorb and digest advanced foreign experience and establish environmental accounting system with Chinese characteristics according to Chinese specific national conditions.

\section{References}

[1]Wang Yiwei. Pan Yue: SEPA is not fighting alone-It's said that environmental information disclosure will have its own laws [N] China Business Times, 2007-2-6

[2]Xiang Shufang, Hu Wei. The construction of corporate environmental information disclosure system of China [J]Beijing: Accounting Research,2005,

[3]Zhou Yihong, Sun Xiaoyan. China listed companies environmental information disclosure empirical analysis [J]Nanjing: Journal of Nanjing Audit University, 2006,(11)

[4]Wei Suyan, Xiao Shufang. Environmental accounting: Related theory and practice [M].Beijing: China Machine Press, 2006

[5]Tang Jiufang. Empirical research of environmental information disclosure-- empirical data of chemical industry from Chinese Security Market[J].China's population, resourses and environment,2008,(05) 